\title{
PENGARUH MINYAK JINTAN HITAM (Nigella sativa L.) TERHADAP DAYA INGAT MENCIT (Mus musculus) JANTAN DENGAN MENGGUNAKAN METODE MAZE RADIAL DELAPAN LENGAN
}

\author{
${ }^{1}$ Ahmad Azrul Zuniarto \\ ${ }^{2}$ Subagja \\ ${ }^{3}$ Nur Imam Komara \\ Prodi Farmasi Sekolah Tinggi Farmasi YPIB Cirebon, aazuniarto@gmail.com
}

\begin{abstract}
ABSTRAK
Penelitian ini bertujuan untuk mengetahui pengaruh minyak jintan hitam (Nigella sativa L.) terhadap daya ingat mencit (Mus musculus) jantan dengan menggunakan metode maze radial delapan lengan dan untuk mengetahui dosis yang memiliki pengaruh untuk meningkatkan daya ingat mencit jantan.

Mencit 15 ekor dibagi menjadi 5 kelompok masing-masing 3 ekor. Diberikan sediaan minyak jintan hitam dosis $0,1 \mathrm{ml} / \mathrm{kg} \mathrm{bb} ; 0,2 \mathrm{ml} / \mathrm{kg} \mathrm{bb} ; 0,3 \mathrm{ml} / \mathrm{kg}$ bb, kontrol positif obat encephabol $0,3 \mathrm{ml} / \mathrm{kg}$ bb dan kontrol negatif aquadest $0,3 \mathrm{ml} / \mathrm{kg}$ bb. Pengujian dilakukan pada hari ke-18 dan data dihitung dari hari ke-1 sampai ke-18 dengan parameter pengamatan meliputi waktu yang ditempuh mencit dalam menemukan makanan pada alat maze. Sebelum diuji mencit dipuasakan selama 12 jam.

Dari hasil penelitian menunjukan bahwa minyak jintan hitam mempunyai pengaruh terhadap daya ingat mencit jantan setara dengan kontrol positif yaitu obat encephabol. Hasil penelitian daya ingat mencit jantan dengan menggunakan metode maze radial delapan lengan berdasarkan uji anava (@<0.05) menunjukan bahwa minyak jintan hitam dosis $0,1 \mathrm{ml} / \mathrm{kg}$ bb sudah memiliki pengaruh terhadap peningkatan daya ingat mencit jantan. Kandungan kimia yang terdapat pada minyak jintan hitam untuk meningkatkan daya ingat adalah asam linoleat (omega 6), asam linolenat (omega 3) dan vitamin (A, B1, B2, B6, C dan E).
\end{abstract}

Kata Kunci : Minyak Jintan Hitam. Nigella sativa (L.). Daya Ingat. Mencit. Maze radial delapan lengan.

\begin{abstract}
This study aims to determine the effect of black cumin oil (Nigella sativa L.) on the memory of male mice using an eight-arm radial maze method and to determine which dose has an effect to improve the memory of male mice.
\end{abstract}


Mice 15 divided into 5 groups each 3 tails. Given black cumin oil dose of $0.1 \mathrm{ml} / \mathrm{kg} b$; $0.2 \mathrm{ml} / \mathrm{kg} \mathrm{bw} ; 0.3 \mathrm{ml} / \mathrm{kg}$ bw, positive control of $0.3 \mathrm{ml} / \mathrm{kg}$ bw encephabol and negative aquadest control of $0.3 \mathrm{ml} / \mathrm{kg}$ bw. The test was performed on the 18th day and the data was calculated from day 1 to 18 with observation parameters including time taken by mice to find food in maze tools. Before tested the mice are fasted for 12 hours.

From the results of research showed that black cumin oil has an effect on the memory of male mice equivalent to the positive control of the drug encephabol. The result of research of male mice with eight angle radial maze method based on anava test (@< < 0.05$)$ showed that black cumin oil dose $0,1 \mathrm{ml} / \mathrm{kg}$ bw already have an effect to increase the memory of male mice. The chemical content found in black cumin oil to improve memory is linoleic acid (omega 6), linolenic acid (omega 3) and vitamins (A, B1, B2, B6, C and E).

Keywords : Black Cumin Oil. Nigella sativa (L.). Memory. Mice. Eight Arm Radial.

\section{PENDAHULUAN}

Penelitian yang dilakukan oleh Prof.G.Reitmuller, Institut Imunologi Munich University, menemukan bahwa dalam biji Jintan Hitam terkandung asam linoleat (omega 6) dan asam linolenat (omega 3). Kedua zat tersebut dapat membantu meningkatkan fungsi kerja otak, seperti menambah kecerdasan, memperkuat daya ingat, relativitas sel otak untuk memperkecil resiko kepikunan, dan membantu memperbaiki peredaran darah pada sel otak. (Handayani, 2013)

Sebelumnya telah dilakukan penelitian di fakultas Farmasi, Cairo University Mesir yaitu minyak Jintan Hitam dengan dosis $1 \mathrm{ml} / \mathrm{bb}$ tikus (200 gram) efektif meningkatkan daya ingat tikus depresi yang diinduksi scopolamine dengan menggunakan metode T-maze dan di fakultas Kedokteran Universitas Gadjah Mada yaitu tikus pasca stress yang diberi eksrtak etanol Pegagan diuji dengan menggunakan metode Maze radial delapan lengan.

Untuk itu dilakukan penelitian pengaruh minyak Jintan Hitam (Nigella sativa L.) terhadap daya ingat mencit (Mus musculus) jantan dengan menggunakan metode Maze radial delapan lengan.

\section{METODE PENELITIAN}

Populasi pada penelitian ini adalah tanaman Jintan Hitam (Nigella sativa L.) dan mencit. Sampel yang digunakan pada penelitian ini adalah biji Jintan Hitam (Nigella sativa L.) dan mencit jantan. Variabel bebas dalam penelitian ini adalah minyak Jintan Hitam (Nigella sativa L.) dengan dengan dosis $0,1 \mathrm{ml} / \mathrm{bb}$ mencit (X1); 0,2 ml/bb mencit (X2); dan 0,3 ml/bb mencit (20 gram) (X3). 
Variabel terikat dalam penelitian ini adalah kemampuan daya ingat mencit menggunakan metode Maze radial delapan lengan (Y).Variabel kontrol dalam penelitian ini yaitu, kontrol positif Encephabol $^{\circledR}$ sirup dan kontrol negatif aquadest.

Pengukuran kemampuan daya ingat mencit dilakukan dengan tes untuk mendapatkan makanan menggunakan Maze radial delapan lengan. Parameter yang dilihat adalah waktu yang ditempuh mencit untuk menemukan makanan pada ruang kecil disalah satu ujung lengan maze. Tahap awal dilakukan adaptasi tiap mencit dalam Maze radial delapan lengan selama 10 menit tanpa pemberian obat dan makanan pada hari ke-0 hingga hari ke-7. Kemudian, dilanjutkan kembali untuk pembelajaran mencit disertai pemberian sediaan uji yang telah disiapkan dan menyimpan umpan makanan pada salah satu ruang kecil ujung lengan maze yaitu lengan ke-5 selama 10 hari, namun sebelumnya mencit dipuasakan terlebih dahulu selama 12 jam. Tahap pengujian kemampuan daya ingat dilakukan setelah pemberian sediaan uji dihentikan, namun umpan makanan tetap diberikan yaitu pada hari ke-18.

Data yang diperoleh dari hasil penelitian dihitung dan divalidasi dengan menggunakan uji statistik ANAVA satu arah dengan aplikasi SPSS yang sebelumnya telah diuji homogenitas dan uji normalitas. Terakhir dilakukan Uji t tujuannya mengetahuai dosis yang paling efektif

\section{PEMBAHASAN}

Mencit yang telah diseleksi dan ditimbang dibagi dalam lima kelompok perlakuan. Waktu yang diperlukan untuk menemukan makanan dicatat setiap hari selama 18 hari.

\section{Tabel 1. Rata-Rata Waktu Mencit Menemukan Makanan (detik)}

\section{Keterangan :}

X3 : Kelompok mencit dengan pemberian Minyak Jintan Hitam Dosis 0,3 ml/kg bb

X2 : Kelompok mencit dengan pemberian Minyak Jintan Hitam Dosis 0,2 ml/ kgbb)

X1 : Kelompok mencit dengan pemberian Minyak Jintan Hitam Dosis 0,1 ml/kg bb 
PharmaXplore

Jurnal Sains dan Ilmu Farmasi
ISSN: 2527-5801

Vol. 2 No 3 Mei 2017

KN : Kelompok mencit dengan pemberian Aquadest

\begin{tabular}{cccccccccccccccccccc}
\hline $\begin{array}{c}\text { Hari } \\
\text { ke-> }\end{array}$ & 1 & $\mathbf{2}$ & $\mathbf{3}$ & $\mathbf{4}$ & $\mathbf{5}$ & $\mathbf{6}$ & $\mathbf{7}$ & $\mathbf{8}$ & $\mathbf{9}$ & $\mathbf{1 0}$ & $\mathbf{1 1}$ & $\mathbf{1 2}$ & $\mathbf{1 3}$ & $\mathbf{1 4}$ & 15 & 16 & 17 & 18 \\
\hline $\mathrm{X} 1$ & 256 & 327 & 378 & 300 & 201 & 138 & 244 & 141 & 111 & 260 & 318 & 244 & 67 & 196 & 97 & 142 & 80 & 124 \\
\hline $\mathrm{X} 2$ & 247 & 157 & 208 & 254 & 199 & 234 & 152 & 252 & 321 & 100 & 392 & 54 & 49 & 41 & 184 & 130 & 76 & 90 \\
\hline $\mathrm{X} 3$ & 200 & 206 & 175 & 141 & 239 & 184 & 210 & 228 & $\mathbf{1 7 4}$ & $\mathbf{1 8 5}$ & $\mathbf{1 6 7}$ & $\mathbf{1 3 4}$ & $\mathbf{1 3 5}$ & $\mathbf{3 8}$ & $\mathbf{1 0 0}$ & $\mathbf{2 3 9}$ & $\mathbf{8 2}$ & 47 \\
\hline $\mathrm{KP}$ & 201 & 262 & 472 & 284 & 313 & 252 & 200 & 56 & 83 & 176 & 311 & 105 & 57 & 266 & 83 & 239 & 37 & 75 \\
\hline $\mathrm{KN}$ & 279 & 160 & 105 & 158 & 198 & 263 & 326 & 197 & 254 & 292 & 141 & 313 & 252 & 292 & 299 & 429 & 232 & 415 \\
\hline
\end{tabular}

KP : Kelompok mencit dengan pemberian Encephabol Sirup

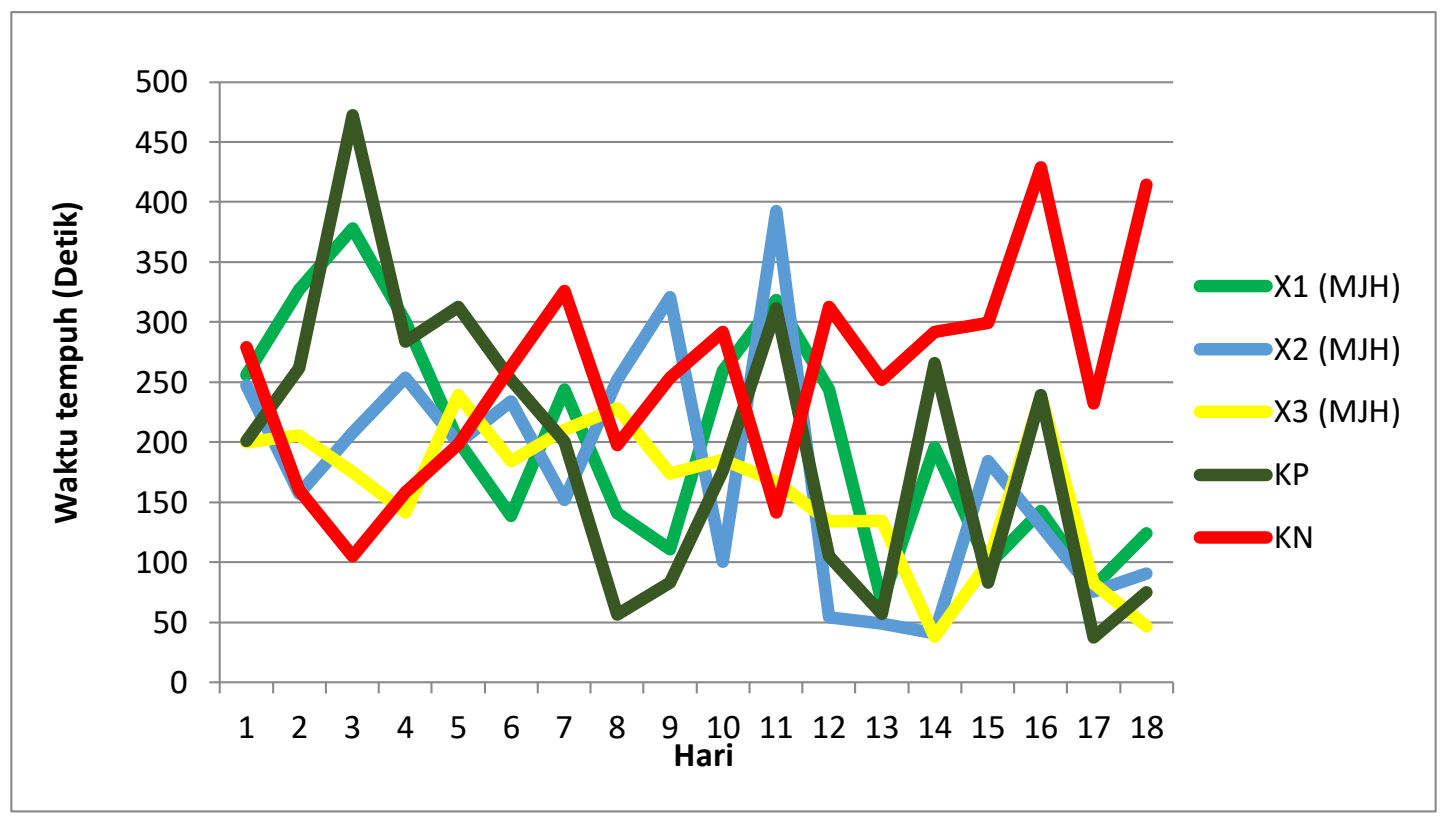

Gambar 1.

Perkembangan mencit dari hari ke-1 - hari ke-18

Grafik 1. Rata-Rata Waktu yang Diperlukan Mencit Menemukan Makanan

Keterangan :

1. Kuning : Kelompok X3 (Minyak Jintan Hitam Dosis 0,3 ml/kg bb)

2. Biru : Kelompok X2 (Minyak Jintan Hitam Dosis 0,2 ml/ kgbb)

3. Coklat : Kelompok K+ (Encephabol Sirup) 
PharmaXplore

Jurnal Sains dan Ilmu Farmasi
ISSN: 2527-5801

Vol. 2 No 3 Mei 2017

4. Merah : Kelompok K- (Aquadest) kg bb)

5. Hijau : Kelompok X1 (Minyak Jintan Hitam Dosis 0,1 ml/kg bb)

Tabel 2. Uji Normalitas, One-Sample Kolmogorov-Smirnov Test

\begin{tabular}{|ll|c|c|c|c|c|}
\hline & & $\mathrm{X} 1$ & $\mathrm{X} 2$ & $\mathrm{X} 3$ & $\mathrm{KP}$ & $\mathrm{KN}$ \\
\hline $\mathrm{N}$ & & 54 & 54 & 54 & 54 & 54 \\
& Mean & 201.37 & 174.48 & 160.20 & 193.37 & 255.85 \\
Normal Parameters ${ }^{\mathrm{a}, \mathrm{b}}$ & Std. & 160.933 & 131.986 & 123.215 & 187.993 & 159.463 \\
& Deviation & & & & & \\
Most Extreme & Absolute & .155 & .142 & .137 & .165 & .141 \\
Differences & Positive & .155 & .142 & .137 & .160 & .141 \\
& Negative & -.122 & -.102 & -.111 & -.165 & -.093 \\
Kolmogorov-Smirnov Z & & 1.140 & 1.043 & 1.004 & 1.210 & 1.038 \\
Asymp. Sig. (2-tailed) & & .148 & .227 & .266 & .107 & .231 \\
\hline
\end{tabular}

Berdasarkan hasil dari perhitungan uji normalitas diperoleh semua nilai (sig.) $>0,05$. Berarti data yang diperoleh berdistribusi normal.

Tabel 3. Uji Homogenitas Data Waktu Tempuh Mencit

\begin{tabular}{|c|c|c|c|}
\hline Levene Statistic & $\mathrm{df1}$ & $\mathrm{df2}$ & Sig. \\
\hline 1.545 & 4 & 265 & .190 \\
\hline
\end{tabular}

Berdasarkan hasil dari perhitungan uji homogenitas diperoleh nilai (sig.) > 0,05. (0,190 > 0,05). Berarti data yang diperoleh homogen.

Tabel 4. Uji Anava

Waktu tempuh mencit dalam menemukan makanan

\begin{tabular}{|l|c|c|c|c|c|}
\hline & Sum of Squares & $\mathrm{df}$ & Mean Square & $\mathrm{F}$ & Sig. \\
\hline Between Groups & 289269.926 & 4 & 72317.481 & 3.032 & .018 \\
Within Groups & 6321382.241 & 265 & 23854.273 & &
\end{tabular}


PharmaXplore

Jurnal Sains dan Ilmu Farmasi
ISSN: 2527-5801

Vol. 2 No 3 Mei 2017

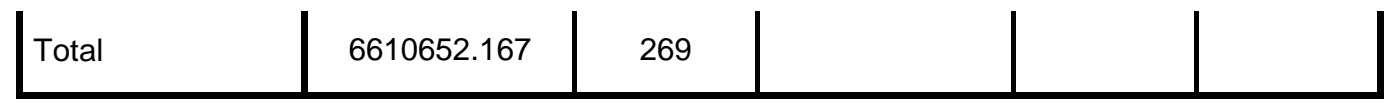

Berdasarkan hasil dari perhitungan uji anava satu arah diperoleh hasil $\mathrm{F}_{\text {hitung }}$ lebih besar dari pada $\mathrm{F}_{\text {tabel }}(3.032>2.405$ ) artinya minyak Jintan Hitam (Nigella sativa L.) dapat mempengaruhi daya ingat mencit menggunakan metode Maze radial delapan lengan.

Tabel 5. Paired Samples Test

Waktu tempuh mencit dalam menemukan makanan

\begin{tabular}{|c|c|c|c|c|c|c|c|c|c|}
\hline & & \multicolumn{5}{|c|}{ Paired Differences } & \multirow[t]{3}{*}{$\mathrm{t}$} & \multirow[t]{3}{*}{$d f$} & \multirow{3}{*}{$\begin{array}{l}\text { Sig. (2- } \\
\text { tailed) }\end{array}$} \\
\hline & & \multirow[t]{2}{*}{ Mean } & \multirow[t]{2}{*}{$\begin{array}{c}\text { Std. } \\
\text { Deviation }\end{array}$} & \multirow[t]{2}{*}{$\begin{array}{l}\text { Std. } \\
\text { Error } \\
\text { Mean }\end{array}$} & \multicolumn{2}{|c|}{$\begin{array}{c}95 \% \text { Confidence } \\
\text { Interval of the } \\
\text { Difference } \\
\end{array}$} & & & \\
\hline & & & & & Lower & Upper & & & \\
\hline Pair 1 & $\mathrm{X} 1-\mathrm{KP}$ & 8.000 & 196.959 & 26.803 & -45.759 & 61.759 & .298 & 53 & .767 \\
\hline Pair 2 & $\mathrm{X} 2-\mathrm{KP}$ & -18.889 & 213.179 & 29.010 & -77.076 & 39.298 & -.651 & 53 & .518 \\
\hline Pair 3 & $\mathrm{X} 3-\mathrm{KP}$ & -33.167 & 225.244 & 30.652 & -94.646 & 28.313 & -1.082 & 53 & .284 \\
\hline
\end{tabular}

Berdasarkan uji t-test pada kemampuan daya ingat mencit diperoleh nilai thitung yang lebih kecil dari pada tabel yaitu pada semua dosis, artinya semua dosis tersebut tidak memiliki perbedaan yang signifikan dengan Kontrol positif.

Minyak Jintan Hitam memiliki pengaruh dalam meningkatkan daya ingat pada mencit jantan menggunakan metode maze radial delapan lengan dengan dilihat dari adanya perbedaan bermakna (sig. < 0.05) dibandingkan dengan kelompok kontrol negatif pada semua dosis penelitian. Minyak Jintan Hitam yang digunakan pada penelitian ini mengandung senyawa Asam linoleat (omega 6), Asam linolenat (omega 3) dan Vitamin (A, B1, B2, B6, C dan E) untuk meningkatkan konsentrasi, memperbaiki daya ingat dan kewaspadaan dimana senyawa tersebut bekerja memberikan nutrisi dan komponen yang dibutuhkan otak serta melindungi otak dari kerusakan sel akibat efek buruk radikal bebas. (Yulianti dan Junaedi, 2006)

Proses pembentukan ingatan terdiri dari 3 tahap, yaitu proses pencataan, penyimpanan, dan pemanggilan kembali informasi yang disimpan oleh areat hipokampus. Proses pembelajaran mencit terhadap alat Maze radial delapan lengan pada hari ke-0 hingga hari ke-7 dianggap sebagai 
PharmaXplore

Jurnal Sains dan Ilmu Farmasi
ISSN: 2527-5801

Vol. 2 No 3 Mei 2017

proses adaptasi mencit terhadap alat atau lingkungan. Selain itu, pada tahap ini juga terjadi proses pencatatan serta penyimpanan informasi yang baru diperoleh.

Kemudian, informasi yang diperoleh tersebut akan disimpan di dalam otak dalam bentuk ingatan jangka pendek. Informasi yang diperoleh dari ingatan jangka pendek dapat mengalami konsolidasi atau perubahan menjadi ingatan jangka panjang melalui latihan aktif atau pengulangan. Proses konsolidasi ini dilakukan melalui latihan aktif mencit setiap harinya selama 10 hari untuk dapat menemukan makanan pada ruang kecil disalah satu ujung Maze yaitu lengan ke-5. Dimana proses peletakkan makanan pada ruang kecil disalah satu ujung Maze yang sama seperti kondisi pada saat pembelajaran daya ingat digunakan, merupakan pemanggilan kembali informasi yang ada di hipokampus yaitu pada hari ke-18. Pada proses konsolidasi terjadi proses pemindahan ingatan hipokampus agar ingatan yang diperoleh lebih bertahan dalam jangka waktu yang lama ke bagian.

\section{PENUTUP}

Minyak Jintan Hitam (Nigella sativa L.) memiliki pengaruh untuk meningkatkan daya ingat mencit (Mus musculus) jantan dengan menggunakan metode Maze radial delapan lengan. Minyak Jintan Hitam (Nigella sativa L.) dengan dosis $0,1 \mathrm{ml} / \mathrm{kg}$ bb; 0,2 ml/kg bb; dan 0,3 ml/kg bb, memiliki pengaruh yang setara dengan kontrol positif untuk meningkatkan daya ingat mencit (Mus musculus) jantan dengan menggunakan metode Maze radial delapan lengan.

\section{DAFTAR PUSTAKA}

Anonim. 2008. Buku pintar TANAMAN OBAT, Agromedia Pustaka, Jakarta

Anonim. 2009. Jintan Hitam, http://grosir-surabaya6.blogspot.co.id/2009/10/jintan-hitam.html. (diakses : 8 Oktober 2016)

Anonim. 2016. OBAT NOOTROPIK \& NEUROTROPIK, http://apotik.medicastore.com/artikelobat/nootropik--neurotonik. (diakses : 8 Oktober 2016)

Anonim. 2013. ENCEPHABOL, http://apotik.berkahanugrah.net/produk-1012-encephabolsyrup.html (diakses : 8 Oktober 2016)

Anonim. 2016. Penyebab Hilang Ingatan dan Cara Mengatasinya, http://www.alodokter.com/penyebab-hilang-ingatan-dan-cara-mengatasinya. (diakses : 8 Oktober 2016) 
PharmaXplore

ISSN: 2527-5801

Jurnal Sains dan Ilmu Farmasi

Crusio, W.E. and Schwegler, H. 2005. Learning Spatial Orientation Tasks In The Radial Maze And Structural Variation In The Hippocampus In Inbred Mice [Review]. Behavioral and Brain Function

El-Marasy, S,A. et al. 2012. Effect of Nigella Sativa and Wheat Germ Oils on ScopolamineInduced Memory Impairment in Rats, http://www.sciencedirect.com/science/article/pii/S1110093112000142. (diakses : 7 September 2016)

Floresco, S.B., Seamans J.K., Philips A.G. 1997. Selective Roles for Hippocampal, Prefrontal Cortical and Ventral Striatal Circuits in Radial Arm Maze Tasks with or without A Delay. J Neurosci

Hamidi, B. L. 2009. Efek Pemberian Ekstrak Ethanol Pegagan (Centella Asiatica) terhadap Kinerja Tikus (Rattus Novergicus) Dalam Maze Radial Delapan Lengan Pasca Restraint Stres, https://eprints.uns.ac.id/. (diakses : 7 September 2016)

Handayani, T. 2013. Hasiat Ampuh Akar-Batang-Daun, Infra Pustaka, Bandar Lampung

Rajsekhar, S. 2015. Pharmacognocy and Pharmacology of Nigella Sativa - A Review, http://www.irjponline.com/. (diakses : 8 Oktober 2016)

Sarwono, J. 2008. Statistik Itu Mudah : Panduan Lengkap Untuk Belajar Komputasi Statistik Menggunakan Spss 16. Andi Yogyakarta, Yogyakarta

Sudjana. 2002. Desain dan Analisa EKSPERIMEN edisi IV, TARSITO, Bandung

Sugiyono. 2006. Metode Penelitian Kuantitatif, Kualitatif, dan R\&D, Alfabeta, Bandung

Suwendar. dkk. 2015. Pengaruh Pemberian Infusa Biji Kacang Hijau (Vigna Radiata (L.) R. Wiclzek) terhadap Daya Ingat Mencit Swiss Webster Jantan Menggunakan Metode Labirin Y, http://karyailmiah.unisba.ac.id/. (diakses : 7 September 2016)

Syamsudin dan Darmono. 2011. Farmakologi Eksperimental, UI Press, Jakarta

Tantomi, A.I. dkk. 2013. Tren Fenomena 'Pisidi' (Pikun Usia Dini) Sebagai Dugaan Awal Gejala Demensia Di Kota Malang, http://artikel.dikti.go.id/index.php/PKM-P/article/view/9. (diakses : 1 Mei 2017)

Yulianti, S. dan Junaedi. 2006. Sembuhkan Penyakit dengan Habbatussauda, Agromedia Pustaka, Jakarta 